\title{
STRATEGI PENGENDALIAN KEBAKARAN HUTAN DI IUPHHK-HT PT FINNANTARA INTIGA PROVINSI KALIMANTAN BARAT
}

\author{
The Strategy of Forest Fire Control in IUPHHK-HT PT Finnantara Intiga West \\ Kalimantan Province
}

Bambang Hero Saharjo ${ }^{1 *}$, Robi Deslia Waldi ${ }^{2}$

(Diterima Maret 2017/Disetujui Desember 2018)

\begin{abstract}
The forest fire control is done through prevention, suppression, and following fire activities at national level and forest unit level. This research was divided in to informan and responden subjects. The implementation strategy of forest fire control in PT Finnantara Intiga adapted from PP Numb. 4 year 2001 about controling damaged forest and or environment pollution that related to forest fire and or land according the provision of article 20 (1) PP Numb. 45 year 2004 about forest protection that declare to prevent and limiting the destruction of forest caused by forest fire, and need to do controling of forest and land fire. The majority of people work as a farmer that have time schedule of land cultivation. The event of forest fire and land in the its highest level that occurs in august to september because in that time most of farmer doing fields burning with average of total extent about 25.8 hectares and the amount of hotspots were about 144 point in the period of 2010 to 2015.
\end{abstract}

Key words: Stretgy, fire prevention control, hotspot

\section{PENDAHULUAN}

Indonesia memiliki luas hutan hujan tropika yang terluas di Asia tropis. Menurut Kementerian Kehutanan dan FAO (1990; 1991) luas hutan Indonesia adalah 144 juta ha, 64.4 juta ha di antaranya berstatus hutan produksi (tetap dan terbatas). Menurut Suratmo et al. (2003), luas hutan tropika di Indonesia diperkirakan adalah 164 juta ha, kemudian berkurang menjadi 143 juta ha, dan pada tahun 1999 diperkirakan tinggal 90120 juta ha, apabila luas daratan Indonesia diperkirakan 190 juta ha maka luas hutan di Indonesia tinggal 4864\% dari daratan. Menurut data dari Kemenhut (2012), kawasan hutan di Indonesia mencapai \pm 137.09 Juta ha.

Kebakaran hutan di Indonesia merupakan pemicu hilangnya hutan tropika Indonesia dan sebagai ancaman potensial bagi pembangunan berkelanjutan. Kebakaran yang terjadi di musim kemarau ini menyebabkan kerusakan ekosistem serta kerugian aspek ekonomi, sosial, dan budaya. Kebakaran hutan yang terbesar terjadi pada tahun 1997 sampai 1998 yang mencapai luasan 9.7 juta ha lahan dengan luasan areal terbakar tersebar di beberapa pulau seperti: Sumatera 1.7 juta ha, Kalimantan 6.5 juta ha, Jawa 0.1 juta ha, Sulawesi 0.4 juta ha, dan Irian Jaya 1 juta ha. Dengan pembagian

\footnotetext{
${ }^{1}$ Staf Pengajar Dept. Silvikultur Fakultas Kehutanan IPB

* Penulis korespondensi:

e-mail: bhherosaharjo@gmail.com

${ }^{2}$ Mahasiswa Dept. Silvikultur Fakultas Kehutanan IPB
}

menurut tipe hutan yang terbakar adalah hutan pegunungan 0.1 juta ha, hutan dataran rendah 3.3 juta ha, gambut 1.5 juta ha, lahan pertanian dan alang-alang terbuka 4.5 juta ha, HTI dan perkebunan 0.3 juta ha. Dengan jumlah kerugian mencapai Rp9.5 Triliun (EEPSEA dan WWF 1998).

Pemerintah Indonesia telah mengeluarkan berbagai kebijakan dalam rangka menangani masalah ini. Beberapa peraturan perundang-undangan yang dilahirkan menekankan sanksi yang berat bagi pelaku pembakaran hutan, yaitu UU No. 41 Tahun 1999 tentang Kehutanan, UU No. 32 Tahun 2009 tentang Perlindungan dan Pengelolaan Lingkungan Hidup, PP No. 60 Tahun 2009 hasil revisi dari PP No. 45 Tahun 2004 tentang Perlindungan Hutan. Melihat kondisi saat ini, banyaknya peraturan tentang kebakaran hutan masih menyebabkan tingginya angka kebakaran hutan menjadi banyak perhatian akademisi dan non-akademisi tentang strategi pengendalian kebakaran hutan yang dilaksanakan. Pengendalian kebakaran hutan secara umum terdiri dari pencegahan, pemadaman, dan penanganan pasca kebakaran yang dilakukan di tingkat nasional hingga tingkat kesatuan pengelolaan hutan.

Tujuan penelitian ini adalah untuk menganalisis strategi pengendalian kebakaran hutan yang diterapkan, mengetahui jumlah partisipasi masyarakat sekitar IUPHHK-HT PT Finnantara Intiga dalam strategi pengendalian kebakaran hutan. 


\section{METODE PENELITIAN}

\section{Waktu dan Tempat Penelitian}

Penelitian ini dilakukan di IUPHHK-HT PT Finnantara Intiga Provinsi Kalimantan Barat pada bulan Februari-April 2016.

\section{Alat dan Bahan}

Alat-alat yang digunakan adalah kuisioner untuk masyarakat dan pegawai, Laptop dengan software Microsoft Excel, Microsoft Word, alat tulis, alat hitung, alat perekam, dan kamera untuk dokumentasi

Bahan yang digunakan dalam penelitian ini yaitu data sekunder (data-data sejarah terjadinya kebakaran), dokumen yang berhubungan dengan strategi pengendalian kebakaran hutan yang diterapkan oleh PT Finnantara Intiga, peta areal kerja PT Finnantra Intiga, peta kerawanan kebakaran hutan dan data hotspot.

\section{Penentuan Responden}

Penelitian ini membagi subjek penelitian menjadi informan dan responden. Informan merupakan pihak yang akan memberikan keterangan tentang pihak lain dan lingkungannya, sedangkan responden merupakan pihak yang memberi keterangan tentang diri dan kegiatan yang dilaksanakan. Pemilihan subjek penelitian tersebut dikenal dengan teknik snowball sampling. Merode ini dilakukan dengan cara memilih orang tertentu yang dipertimbangkan akan memberikan data yang diperlukan, selanjutnya berdasarkan data atau informasi yang diperoleh dari sampel sebelumnya itu peneliti dapat menetapkan sampel lainnya yang dipertimbangkan akan memberikan data lebih lengkap (Sugiyono 2008).

Responden yang dipilih sebanyak 50 orang yang terdiri dari karyawan tetap dan tidak tetap yaitu pihak yang bergerak dalam bidang yang berkaitan dengan penerapan strategi pengendalian kebakaran hutan IUPHHK-HT (PT Finnantara Intiga) dengan penggunaan informasi dari pimpinan perusahaan. Informan yang dipilih sebanyak 180 orang yang tinggal berdekatan dengan Base Camp Perusahaan, berasal dari enam desa dari dua kabupaten dalam hal ini adalah masyarakat sekitar Desa Sejirak, Ratu Damai, dan Sei. Tamang di Kabupaten Sintang serta Desa Mengkiang, Nanga Biang, dan Pana di Kabupaten Sanggau dengan informasi yang digunakan berdasarankan informasi dari kepala dusun.

\section{Pengumpulan Data}

Data penelitian terdiri dari data primer dan data sekunder. Data primer diperoleh dari subjek penelitian melalui proses wawancara mendalam dan pengamatan berperan-serta mengacu pada metode tri-angulasi (Sitorus 1998). Data sekunder merupakan dokumendokumen yang berkaitan dengan sejarah (yaitu: kapan dan di mana lokasi terjadinya kebakaran, apa penyebab, dan bagaimana terjadinya kebakaran serta berapa luas kerusakan yang ditimbulkan).

\section{Analisis Data}

Metode analisis yang digunakan dalam pengolahan data yaitu bergerak di antara 4 sumbu yaitu pengumpulan data, reduksi data, penyajian data, dan penarikan kesimpulan (Miles dan Haberman dalam Sitorus 1998). Pengolahan dan analisis data ditujukan untuk dapat mendeskripsikan penerapan strategi pengendalian kebakaran hutan di PT Finnantara Intiga serta bentuk partisipasi masyarakat sekitar dan upaya yang dilakukan pihak PT Finnantara Intiga dalam meningkatkan partisipasi masyarakat dalam upaya strategi pengendalian kebakaran hutan yang diterapkan.

\section{KONDISI UMUM LOKASI PENELITIAN}

PT Finnantara Intiga bekerja atas dasar Surat Keputusan IUPHHK HTI dalam Hutan Tanaman No. 750/Kpts-II/1996 pada tanggal 2 Desember 1996. Luas Areal berdasarkan SK Menhut Tersebut adalah seluas 299.700 ha. Menurut pembagian wilayah Administrasi, Areal PT Finnantara Intiga terletak di Provinsi Kalimantan Barat meliputi kecamatan Bonti, Jangkang, Mukok, Sanggau, Kapuas, Parindu berada di Kabupaten Sanggau, dan Kecamatan Sekadau Hilir, Belitang Hulu, Belitang Hilir berada di Kabupaten Sekadau, serta Kecamatan Sepauk, Ketungau Hulu, Ketungau Tengah, Ketungau Hilir, Tempunak berada di Kabupaten Sintang.

Berdasarkan pembagian Pemangkuan Hutan, areal IUPHHK-HT PT. Finnantara Intiga termasuk kedalam wilayah BKPH Dinas Kehutanan dan Perkebunan Kabupaten Sanggau, dan Dinas Kehutanan, Perkebunan dan Pertambangan Kabupaten Sekadau, serta Dinas Kehutanan dan Perkebunan Kabupaten Sintang. Berdasarkan pembagian kesatuan wilayah Daerah aliran Sungai (DAS), areal IPUHHK-HT PT. Finnantara Intiga termasuk wilayah RPH Dinas Kehutanan Provinsi Kalimantan Barat tepatnya di kelompok Hutan Sungai Mengkiyang, Sungai Sekayan, Sungai Beltang, dan Sungai Ketungau. Secara geografis, areal IUPHHK-HT PT. Finnatara Intiga merupakan areal yang terletak di antara $0^{\circ} 00^{\prime} \mathrm{LU}-0^{\circ} 50^{\prime} \mathrm{LU}$ dan $110^{\circ} 30^{\circ} \mathrm{BT}-111^{\circ} 40^{\prime} \mathrm{BT}$.

Topografi areal IUPHHK-HT PT Finnantara Intiga dengan persentase kemiringan lapangan, luas areal kemiringan, dan persentase luas umumnya datar $78,8 \%$ $(0-8 \%)$, landai $0 \%(8-15 \%)$, bergelombang $15,3 \%(16-$ $25 \%$ ), agak curam $4,2 \%$ (25-40\%), dan curam $1,7 \%$ $(>40 \%)$. Areal tersebut memiliki ketinggian minimum $11 \mathrm{~m}$ dpl dan maksimum $300 \mathrm{~m}$ dpl.

Tipe hutan di areal IUPHHK-HT PT. Finnantara Intiga Provinsi Kalimantan Barat termasuk tipe hutan hujan tropis (Low Land Tropical Rain Forest). Jenis tanaman yang ditanam di IUPHHK-HT PT. Finnantara Intiga adalah tanaman pokok terdiri dari: Eucalyptus pellita, Acacia mangium, dan Acacia crasiccarpa sebagai pemasok industri jenis kayu serat. Jenis lain yang ditanam adalah tanaman unggul di antaranya Meranti (Shorea sp.) dan Ulin (Eusiderxylon zwageri). Terdapat juga jenis lain adalah tanaman kehidupan seperti Karet (Hevea brasilliensis). Selain itu, keadaan hutan di arehal IUPHHK-HT PT. Finnantara Intiga 
berdasarkan luasan pada tipe hutan. Areal kerja PT Finnatara Intiga seluas \pm 299700 ha tersebar di tiga kabupaten, di Provinsi Kalimantan Barat yang meliputi 13 kecamatan, yaitu kecamatan Bonti, Jangkang, Mukok, Sanggau, Kapuas, Parindu berada di Kabupaten Sanggau, dan Kecamatan Sekadau Hilir, Belitang Hulu, Belitang Hilir berada di Kabupaten Sekadau, serta Kecamatan Sepauk, Ketungau Hulu, Ketungau Tengah, Ketungau Hilir, Tempunak berada di Kabupaten Sintang. Di dalam dan sekitar areal kerja tersebut teridentifikasi sebanyak 66 desa hutan, yang terdiri dari 61 desa di dalam areal IUPHHK dan 5 desa di luar areal IUPHHK.

\section{HASIL DAN PEMBAHASAN}

\section{Hubungan Hotspot dan Luas Tanaman Terbakar terhadap Strategi Pengendalian Kebakaran Hutan di PT Finnantara Intiga}

Berdasarkan dokumen kejadian kebakaran hutan yang terjadi di PT Finnantara Intiga diperoleh data hotspot dan luasan tanaman Acacia mangium dan Eucalyptus pellita per bulan terbakar periode 20102015 yang dapat dilihat pada Tabel 1 dan Tabel 2.

Penyebaran hotspot tiap bulannya, banyak ditemukan pada bulan Agustus dan September. Total hotspot yang ditemukan periode 2010-2015 pada bulan Agustus sebanyak 276 hotspot dan bulan September ditemukan sebanyak 336 hotspot. Berdasarkan informasi hotspot yang diterima oleh perusahaan maka seharusnya kebakaran hutan dapat diminimumkan sehingga tidak akan ada lahan tanaman yang terbakar. Luas lahan tanaman terbakar dapat dilihat pada Tabel 1.

Berdasarkan Tabel 2, data luasan tanaman terbakar periode 2010-2015 bahwa kejadian kebakaran hutan ini terluas dan hotspot tertinggi terjadi pada bulan September (Tabel 1). Jumlah hotspot tertinggi dengan total 336 titik pada bulan September menyebabkan terbakarnya hutan seluas $31.58 \mathrm{Ha}$. Tanaman yang terbakar semuanya bersebelahan langsung dengan ladang masyarakat. Hal ini menjadi alasan perusahaan bahwa kebakaran disebabkan oleh masyarakat yang melakukan kegiatan perladangan berpindah, sehingga api yang dijadikan dalam proses pembakaran ladang berpindah menjalar ke tanaman perusahaan.

Pada Gamabr 1 menunjukkan respon masyarakat terkait penyebab kebakaran hutan yang terjadi di PT Finnantara Intiga. Berdasarkan hasil wawancara informan menjelaskan bahwa sebagian masyarakat tidak mengetahui asal muasal api yang membakar hutan tanaman perusahaan. Informan sebesar 60\% menjelaskan bahwa kebakaran itu lebih disebabkan oleh api liar atau api loncat yang dianggap masyarakat bukan berasal dari ladang berpindah. Adapun kejadian kebakaran yang disebabkan oleh perladangan sekitar $36 \%$. Hal ini berarti masyarakat sudah mengetahui cara pembakaran berladang berpindah agar tidak terjadi kebakaran dengan membuat sekat bakar. Masyarakat

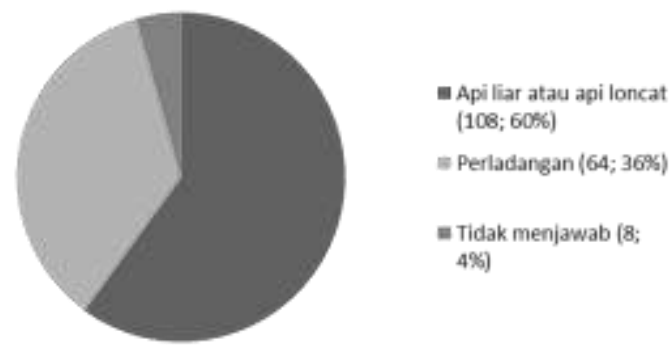

Gambar 1 Penyebab kebakaran hutan di PT Finnantara Intiga

Tabel 1 Data hotspot bulanan PT Finnantara Intiga periode 2010-2015

\begin{tabular}{|c|c|c|c|c|c|c|c|c|c|c|c|c|c|}
\hline \multirow{2}{*}{ Tahun } & \multicolumn{12}{|c|}{ Bulan } & \multirow{2}{*}{ Total } \\
\hline & 1 & 2 & 3 & 4 & 5 & 6 & 7 & 8 & 9 & 10 & 11 & 12 & \\
\hline 2010 & - & - & - & - & - & - & - & 6 & 9 & 35 & - & 1 & 51 \\
\hline 2011 & 1 & - & - & 3 & 1 & - & 5 & 70 & 80 & 1 & - & - & 161 \\
\hline 2012 & - & - & - & 1 & 2 & - & 4 & 28 & 156 & 2 & - & 1 & 194 \\
\hline 2013 & 2 & - & 2 & - & 2 & 1 & - & 37 & - & - & - & - & 44 \\
\hline 2014 & - & 2 & 2 & 3 & - & 3 & 16 & 32 & 51 & 4 & - & - & 113 \\
\hline 2015 & - & - & - & - & - & 1 & 12 & 103 & 40 & - & - & - & 156 \\
\hline Total & 3 & 2 & 4 & 7 & 5 & 5 & 37 & 276 & 336 & 42 & - & 2 & 719 \\
\hline
\end{tabular}

Sumber: Data hotspot PT Finnantara Intiga periode 2010-2015

Tabel 2 Data luas tanaman Acacia mangium dan Eucalyptus pellita terbakar di PT Finnantara Intiga Provinsi Kalimantan Barat periode 2010-2015

\begin{tabular}{cccccccccccccc}
\hline \multirow{2}{*}{ Tahun } & \multicolumn{1}{c}{} & \multicolumn{1}{c}{ Bulan (Ha) } & \multicolumn{1}{c}{ Total (Ha) } \\
\cline { 2 - 10 } 2010 & 1 & 2 & 3 & 4 & 5 & 6 & 7 & 8 & 9 & 10 & 11 & 12 & 1.32 \\
2011 & - & - & - & - & - & - & - & - & 0.14 & 1.18 & - & - & 35.10 \\
2012 & - & - & - & - & - & - & - & 15.41 & 19.69 & - & - & - & 4.03 \\
2013 & - & - & - & - & - & - & - & - & 4.03 & - & - & - & 3.95 \\
2014 & - & 5.14 & - & - & - & - & 6.89 & 4.58 & 6.96 & - & - & - & 23.57 \\
2015 & - & - & 1.20 & - & - & - & 0.77 & 3.30 & 4.80 & - & - & - & 10.07 \\
Total & - & 5.14 & 1.20 & - & - & - & 7.66 & 26.24 & 31.58 & 1.18 & - & - & 73.00 \\
\hline
\end{tabular}


mengangap bahwa dengan membuat sekat bakar maka api dari pembukaan ladang tidak akan menjalar ke tanaman perusahaan. Informan yang tidak merespon penyebab kebakaran hutan di PT Finnantara Intiga sebesar 4\%, karena masyarakat belum merasa diuntungkan dengan adanya perusahaan tersebut. Perbedaan pendapat di antara perusahaan dan masyarakat menjelaskan bahwa di antara perusahaan dan masyarakat belum memiliki rasa tanggung jawab dalam pengendalian kebakaran hutan dan lahan. Perbedaan pendapat ini dikarenakan masyarakat belum sepenuhnya dilibatkan dalam kegiatan perusahaan seperti pembuatan lubang tanam, penanaman, pengendalian hama dan penyakit, dan lain-lain. Pihak perusahaan menilai bahwa kerjasama dengan masyarakat setempat banyak yang kurang diuntungkan seperti masih maraknya okuvasi lahan dan pencabutan tanaman Acacia mangium dan Eucalyptus pellita di PT Finnantara Intiga.

Data luas tanaman Acacia mangium dan Eucalyptus pellita terbakar di PT Finnantara Intiga (2010-2015) disajikan pada Tabel 2. Berdasarkan Tabel 2 dapat dijelaskan bahwa kejadian kebakaran hutan di PT Finnantara Intiga terluas terjadi pada tahun 2011, dengan total luas 35.10 ha dengan jumlah hotspot 161 titik. Pada tahun 2011 PT Finnantara Intiga tidak melakukan kegiatan pengawasan pada masyarakat saat melakukan perladangan berpindah di bulan September. Namun sebaliknya pada tahun 2012 luas tanaman terbakar hanya mencapai 4.03 ha dengan jumlah hotspot 194 titik. Hal ini terjadi karena pada tahun 2012 PT Finnantara Intiga melakukan pengawasan terhadap masyarakat dan membuka posko laporan pembukaan ladang yang menerapkan perladangan berpindah dibakar sehingga PT Finnantara Intiga akan memerintahkan 2 orang dari Regu Pemadam Kebakaran (RPK) untuk mengawasi kegiatan tersebut.

\section{Strategi Pengendalian Kebakaran hutan di PT Finnantara Intiga}

Penerapan strategi pengendalian kebakaran hutan di PT Finnantara Intiga disesuaikan dengan Peraturan Pemerintah Republik Indonesia Nomor 45 Tahun 2004 pasal 20 ayat 1 yang menyatakan bahwa untuk mencegah dan membatasi kerusakan hutan yang disebabkan oleh kebakaran sebagaimana pada pasal 6 huruf a, dilakukan kegiatan pengendalian, yang meliputi: a. pencegahan; b. pemadaman; dan c. penanganan pasca kebakaran.

\section{A. Pencegahan kebakaran hutan}

PT Finnantara Intiga memiliki beberapa parameter atau kegiatan dalam melaksanakan pencegahan kebakaran hutan dan lahan. Berdasarkan hasil wawancara kepada responden 50 orang dapat dilihat bahwa komponen strategi pencegahan kebakaran hutan dapat dilihat pada tabel 3 .

Berdasarkan Tabel 3 dapat dijelaskan bahwa komponen atau kegiatan pencegahan yang dilakukan di PT Finnantara Intiga memiliki perencanaan yang baik dalam mencegah terjadinya kebakaran hutan dan lahan. Informasi yang diberikan oleh responden bahwa komponen atau kegiatan yang direncanakan oleh PT Finnantara Intiga termasuk pada Peraturan Pemerintah Republik Indonesia Nomor 45 Tahun 2004 pasal 23 ayat 1 huruf d nomor 1. Kejadian Kebakaran hutan di PT Finnantara Intiga dapat diminimumkan apabila parameter atau kegiatan yang sudah direncanakan oleh manajemen PT Finnantara Intiga dalam komponen pencegahan kebakaran hutan ini benar-benar dilaksanakan atau dijalankan dengan baik di lapang.

Pada kenyataannya di lapangan, PT Finnantara Intiga hanya melakukan beberapa kegiatan pencegahan kebakaran yang direncanakan seperti pembentukan

Tabel 3 Komponen strategi pencegahan kebakaran hutan PT Finnantara Intiga

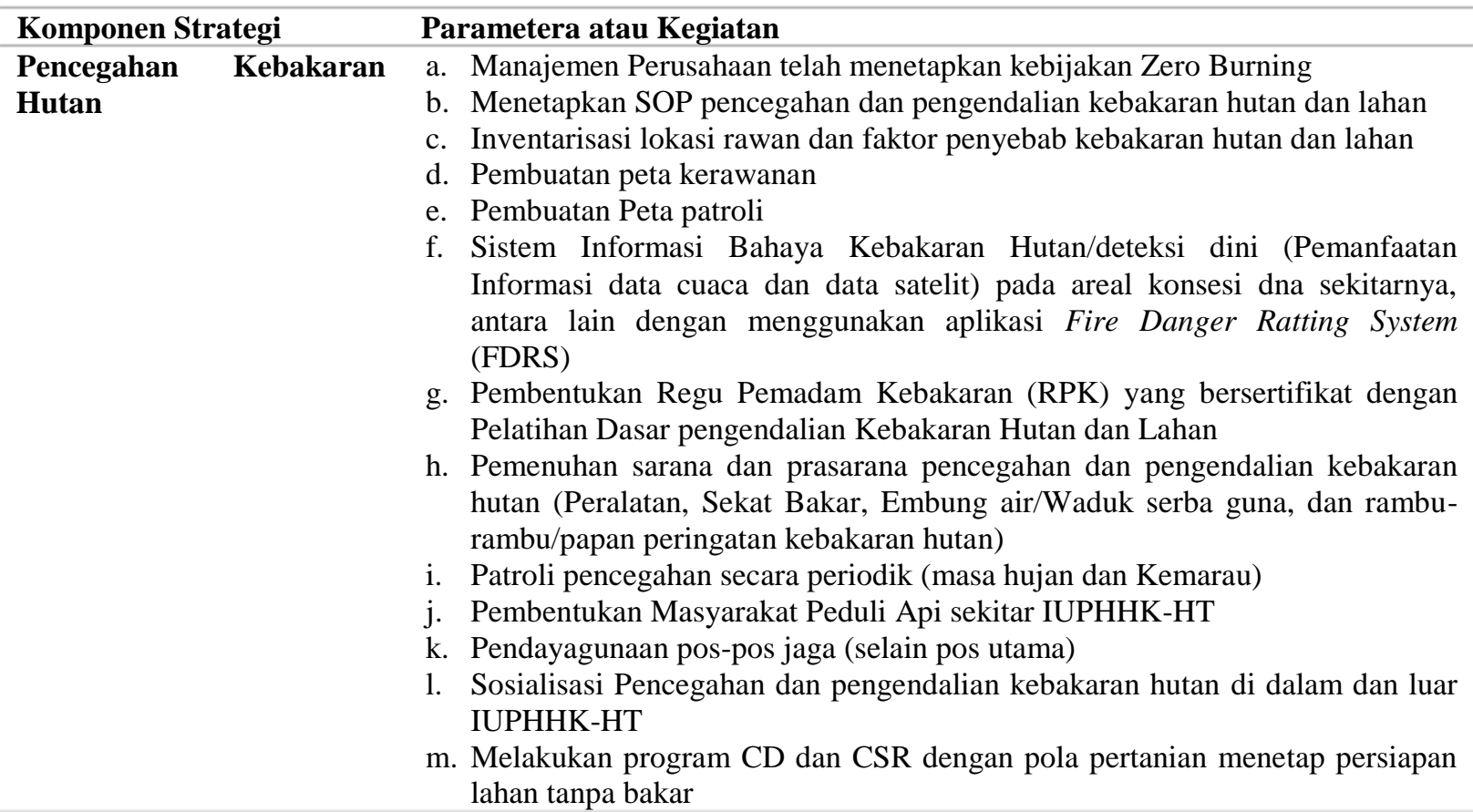

Sumber: Hasil wawancarara dengan 50 orang responden 
Regu Pemadam Kebakaran (RPK), pelatihan pengendalian kebakaran hutan dan lahan, pemenuhan sarana, dan parsarana pengendalian kebakaran hutan dan lahan, sosialisasi serta penyuluhan pengendalian kebakaran hutan dan lahan. Pembentukan Regu Pemadam Kebakaran (RPK) dan pelatihan pengendalian kebakaran hutan hanya dilakukan sekali diawal tahun. Jumlah personil pemadam kebakaran yang ada belum mewakili luas lahan yang ada di PT Finnantara Intiga yaitu 145 orang yang seharusnya berdasarkan Keputusan Direktur Jenderal Perlindungan Hutan dan Pelestarian Alam No. 243/kpts/DJ-IV/1994 bahwa jumlah personil 1 orang untuk setiap 1000-2000 ha, artinya PT Finnantara Intiga dengan luas 299.700 ha harus memiliki 300 orang bila 1 orang mewakili 1000 ha atau 150 orang bila 1 orang mewakili 2000 ha.

Informasi dari informan mengenai kegiatan sosialisasi dan/atau penyuluhan pengendalian kebakaran hutan yang dilakukan oleh perusahaan disajikan pada Gambar 2. Informan menjelaskan bahwa 93\% mengetahui kegiatan sosialisasi dan/atau penyuluhan dilakukan oleh PT Finnantara Intiga meskipun dilakukan satu kali dalam setahun mendekati musim kemarau dan $7 \%$ tidak mengetahui informasi kegiatan sosialisasi dan/atau penyuluhan yang dilakuakan oleh PT Finnantara Intiga karena kurangnya publikasi dan informasi yang diberikan terkait waktu kegiatan tersebut. Hal ini menjelaskan bahwa hampir seluruhnya

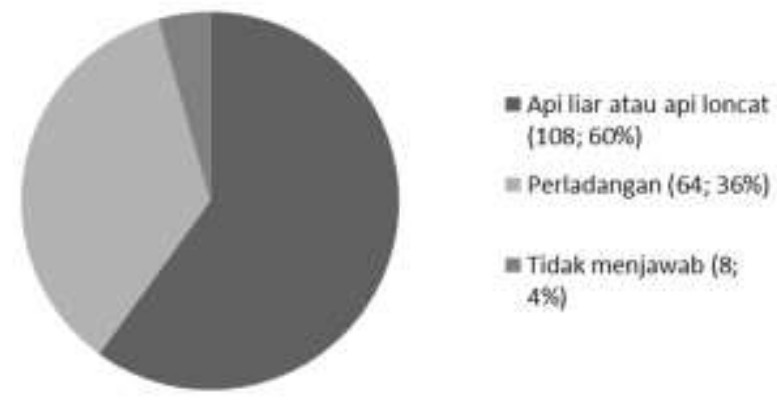

Gambar 2 Informasi kegiatan sosialisasi dan/atau penyuluhan pengendalian kebakaran hutan oleh PT Finnantara Intiga

masyarakat mengetahui dan mengikuti kegiatan yang dilakukan oleh PT Finnantara Intiga. Akan tetapi masyarakat belum sepenuhnya melaksanakan dan mengikuti pelaksanaan di lapahng karena dianggap perusahaan terlalu menyudutkan masyarakat dalam kejadian kebakaran hutan, Pembukaan Lahan Tanpa Bakar (PLTB) atau program cetak sawah memerlukan biaya mahal, dan perusaan pun masih setengah-setengah dalam mensosialisasikannya.

\section{B. Pemadaman kebakaran hutan}

Pemadaman kebakaran hutan adalah serangkaian kegiatan yang ditujukan untuk mematikan api yang membakar hutan. PP No. 45 tahun 2004 tentang Perlindungan Hutan, pasal 24 ayat 1 menyebutkan bahwa pemegang Izin Pemanfaatan Hutan, Pemegang Izin Penggunaan Kawasan Hutan, Pemilik Hutan Hak dan atau Kepala Kesatuan Pengelolaan Hutan, berkewajiban melakukan rangkaian tindakan pemadaman dengan cara:

1. Melakukan deteksi terjadinya kebakaran hutan,

2. Mendayagunakan seluruh sumber daya yang ada,

3. Membuat sekat bakar dalam rangka melokalisir api, dan

4. Memobilisasi masyarakat untuk mempercepat pemadaman.

Dilanjutkan pada Pasal 24 ayat 2 yang menyebutkan bahwa Pemegang Izin Pemanfaatan Hutan, Pemegang Izin Penggunaan Kawasan Hutan dan atau Kepala Kesatuan Pengelolaan Hutan melakukan:

a. Koordinasi dengan instansi terkait dan tokoh masyarakat dalam rangka mempercepat pemadaman, evakuasi, litigasi, dan mencegah bencana,

b. Pelaporan kepada Bupati/Walikota tentang kebakaran hutan yang terjadi dan tindakan pemadaman yang dilakukan.

Berdasarkan Tabel 4 dapat dinyatakan bahwa kegiatan pemadaman yang dilakukan di PT Finnantara Intiga memiliki perencanaan yang baik dalam memadamkan api saat terjadinya kebakaran hutan dan lahan. Informasi yang diberikan oleh responden menjelaskan bahwa komponen atau kegiatan yang direncanakan oleh PT Finnantara Intiga termasuk pada Peraturan Pemerintah Republik Indonesia Nomor 45 Tahun 2004 pasal 24 ayat 1. Pemadaman Kebakaran hutan sebenarnya dapat dilakuakan dengan baik apabila perencanaan yang sudah dibuat oleh PT Finnantara Intiga ini dilaksanakan atau dijalankan dengan baik di

Tabel 4 Komponen strategi pemadaman kebakaran hutan PT Finnantara Intiga

\begin{tabular}{|c|c|}
\hline Komponen Strategi & Parameter/Kegiatan \\
\hline $\begin{array}{l}\text { Pemadaman Kebakaran } \\
\text { Hutan }\end{array}$ & $\begin{array}{l}\text { a. Menetapkan dan menerapkan prosedur Incident Commend System (ICS) } \\
\text { (Sistem Komando Penanganan) } \\
\text { b. Posko Siaga Pemadaman atau Situation Room tingkat distrik Distrik dan } \\
\text { Region } \\
\text { c. Menentukan taktik dan strategi pemadaman (Pemadaman awal dan } \\
\text { pemadaman lanjutan) } \\
\text { d. Mengatur komando pengendalian (Pemadaman gabungan dan koordinasi } \\
\text { pemadaman) } \\
\text { e. Melakukan mobilisasi sumberdaya pemadaman kebakaran hutan (Mesin } \\
\text { mesin dan peralatan lainnya yang dibutuhkan, dan SDM) } \\
\text { f. Melaksanakan kegiatan pemadaman kebakaran hutan dan lahan } \\
\text { g. De-mobilisasi Sumberdaya yang digunakan }\end{array}$ \\
\hline
\end{tabular}

Sumber: Hasil wawancarara dengan 50 orang responden 
lapang.

Berdasarkan pelaksanaannya di lapangan, PT Finnantara Intiga tidak melaksanakan pembuatan sekat bakar yang dapat berfungsi menghambat penjalaran api dan memudahkan dalam proses pemadaman. Pemadaman kejadian kebakaran hutan ini ikut serta melibatkan masyarakat yaitu Masyarakat Peduli Api (MPA) yang dibentuk oleh perusaahan sebanyak 2 orang per kampung. Masyarakat Peduli Api (MPA) memiliki fungsi melaporkan kejadian kebakaran hutan di wilayah kampungnya dan ikut serta dalam memadamkan api dengan peralatan yang diberikan oleh perusahaan seperti solo sprayer. Berdasarkan hasil wawancara bahwa tingkat partisipasi masyarakat dalam mengikuti kegiatan pemadaman kebakaran hutan di PT Finnantara Intiga cukup tinggi yaitu sebesar 57\% ikut serta pemadaman meskipun bukan anggota dari Masyarakat Peduli Api (MPA), mereka ikut serta karena ditakutkan api yang menjalar semakin luas dan dapat menjalar ke pemukiman warga, 34\% ikut serta pemadaman karena merupakan anggota dari Masyarakat Peduli Api (MPA), 7\% masyarakat tidak ikut serta

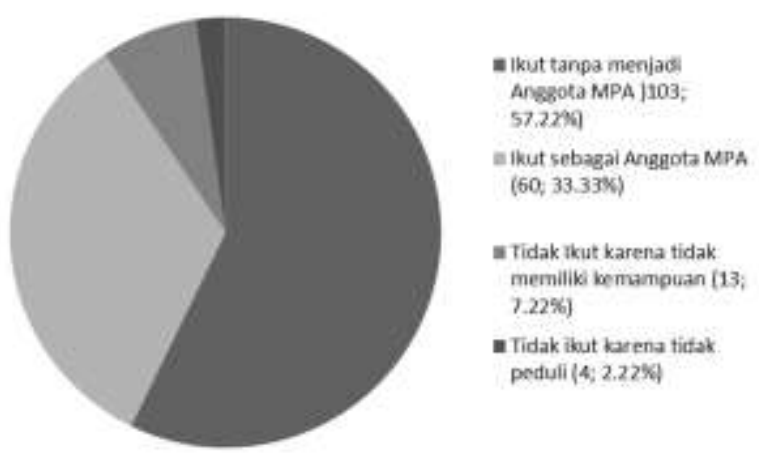

Gambar 3 Tingkat partisipasi masyarakat dalam pemadaman kebakaran hutan dan lahan

pemadaman karena tidak memiliki kemampuan dalam memadamkan api, dan $2 \%$ tidak ikut serta pemadaman kebakaran hutan karena beranggapan perusahaan sudah memiliki Regu Pemadam Kebakaran (RPK) yang tidak membutuhkan masyarakat untuk ikut serta dalam memadamkan kejadian kebakaran hutan dan lahan. Tingkat partisipasi masyarakat dalam pemadaman kebakaran hutan dapat dilihat pada Gambar 3.

Kegiatan pemadaman kebakaran hutan yang dilakukan oleh PT Finnantara Intiga dengan melibatkan masyarakat untuk ikut berpartisipasi harus terus ditingkatkan. Peningkatan partisipasi masyarakat dalam pengendalian kebakaran hutan dipengaruhi beberapa faktor yang harus dilakukan oleh PT Finnantara Intiga seperti pemberian kesempatan pengolahan lahan kepada masyarakat untuk ikut menjaga hutan dari kebakaran, pemberian intensif dalam bentuk pengembangan produk-produk alternatif yang dapat dihasilkan masyarakat (contoh: kerajinan tangan tenun).

\section{Penanganan pasca kebakaran hutan}

Penanganan pasca kebakaran hutan menurut Peraturan Menteri Kehutanan Nomor: P.12/MenhutII/2009 tentang pengendalian kebakaran hutan adalah semua usaha, tindakan atau kegiatan yang meliputi inventarisasi, monitoring dan evaluasi serta koordinasi dalam rangka menangani suatu areal terbakar. Menurut PP No 45 tahun 2004 tentang Perlindungan Hutan, Pasal 27 menyebutkan bahwa dalam rangka penanganan pasca kebakaran hutan sebagaimana dimaksud pasal 20 ayat 1 huruf c, dilakukan upaya kegiatan yang meliputi: a. identifikasi dan evaluasi, b. Rehabilitasi, dan c. penegakan hukum.

PP No. 45 Pasal 28 menyebutkan bahwa:

1. Kepala Kesatuan Pengelola Hutan, Pemegang Izin Pemanfaatan Hutan, Pemegang Izin Penggunaan Kawasan Hutan, atau Pemilik Hutan Hak melakukan kegiatan identifikasi dan evaluasi sebagaimana dimaksud dalam Pasal 27 huruf a.

2. Kegiatan identifikasi dan evaluasi sebagaimana dimaksud pada ayat 1 , berupa:

a. Pengumpulan data dan informasi terjadinya kebakaran.

b. Pengukuran dan sketsa lokasi kebakaran.

c. Analisis tingkat kerusakan dan rekomendasi.

3. Ketentuan lebih lanjut mengenai identifikasi dan evaluasi sebagaimana dimaksud pada ayat ayat 2 diatur oleh Menteri.

PP No. 45 pasal 29 menyebutkan bahwa:

1. Berdasarkan hasil kegiatan sebagaimana diamksud dalam Pasal 28 ayat 2, dilakukan kegiatan rehabilitasi.

2. Kegiatan rehabilitasi dilakukan oleh Kepala Kesatuan Pengelola Hutan, Pemegang Izin Pemanfaatan Hutan, Pemegang Izin Penggunaan Kawasan Hutan, atau Pemilik Hutan Hak.

3. Kegiatan rehabilitasi diatur dalam Peraturan Pemerintah tersendiri.

Berdasarkan Tabel 5 dapat dijelaskan bahwa

Tabel 5 Komponen strategi penanganan pasca kebakaran hutan PT Finnantara Intiga

\begin{tabular}{ll}
\hline Komponen Strategi & Parameter/Kegiatan \\
\hline Penanganan Pasca & a. Melaporkan kejadian kebakaran hutan secara internal : Reall time dengan \\
Kebakaran Hutan & cara Fire Reporting online System (FROS) \\
& b. Melaporkan kejadian kebakaran hutan secara tertulis kepada pihak \\
& eksternal (Kepala Desa, Camat, Kepolisan, Dinas Kehutanaan kabupaten \\
& dan provinsi) \\
& c. Pengecekan dan verifikasi lokasi kejadian kebakaran dan pembuatan Berita \\
& Acara Pemeriksaan (BAP) \\
d. Tindak lanjut melalui proses penyelesaian secara sosial dan hukum positif \\
e. Rehabilitasi areal terbakar
\end{tabular}

Sumber: Hasil wawancara dengan 50 orang responden 
kegiatan penanganan pasca yang dilakukan di PT Finnantara Intiga memiliki perencanaan yang baik. Informasi yang diberikan oleh responden menjelaskan bahwa kegiatan yang direncanakan oleh PT Finnantara Intiga termasuk pada Peraturan Pemerintah Republik Indonesia Nomor 45 Tahun 2004 pasal 27, pasal 28, dan pasal 29. Penanganan pasca kebakaran hutan sebenarnya dapat dilakukan dengan baik apabila perencanaan yang sudah dibuat oleh PT Finnantara Intiga ini dilaksanakan atau dijalankan dengan baik di lapang.

Penanganan pasca kebakaran hutan yang dilakukan di PT Finnantara Intiga pada Tabel 5, diantaranya melaporkan kejadian kebakaran hutan secara internal menggunakan Fire Reporting Online System (FROS), melaporkan kejadian kebakaran hutan secara tertulis kepada pihak eksternal (Kepala desa, Camat, Kepolisian, Dinas Kehutanan Kabupaten dan Provinsi), pengecekan dan verifikasi lokasi kebakaran hutan dan pembuatan Berita Acara Pemeriksaan (BAP) serta tindak lanjut melalui proses penyelesaian secara sosial dan hukum positif.

\section{SIMPULAN DAN SARAN}

\section{Simpulan}

Peristiwa kebakaran hutan dan lahn yang terjadi di PT Finnantara Intiga diakibatkan oleh api loncat sebesar $60 \%$ dan penjalaran dari perladangan masyarakat sebesar 36\%. Strategi pengendalian kebakaran hutan yang diterapkan di PT Finnantara Intiga mengacu pada perencanaan yang sudah dibuat oleh manajemen yang mengacu pada Peraturan Pemerintah Republik Indonesia Nomor 45 Tahun 2004 tentang Perlindungan Hutan. Strategi pengendalian kebakaran hutan yang diterapkan mencakup kegiatan pencegahan, pemadaman dan penanganan pasca kebakaran hutan yang belum dilaksanakan secara maksimal dilapang dikarenakan masih adanya kejadian kebakaran hutan yang terjadi. Masih adanya kejadian kebakran hutan ini karena belum maksimalnya pengawasan dan kerjasama PT Finnantra Intiga dengan masyarakat dalam pengendalian kebakaran hutan sehingga masih terjadi kesalahpahaman atau perbedaan pendapat di antara keduanya.

Partisipasi masyarakat yang berada di sekitar kawasan konsesi merupakan hasil pembentukan dan pembinaan PT Finnantara Intiga dengan adanya kegaitan sosialisasi dan/atau penyuluhan pengendalian kebakaran hutan dan lahan. Kelompok masyarakat tersebut adalah Masyarakat Peduli Api (MPA) yang bekerja untuk melaporkan kejadian kebakaran hutan dan ikut serta memadamkan api dengan peralatan yang diberikan perusahaan seperti solo sprayer. Tingkat partisipasi masyarakat PT Finnantara Intiga cukup tinggi yaitu 57\% ikut serta meskipun bukan anggota dari Masyarakat Peduli Api (MPA) karena ditakutkan api menjalar ke pemukiman warga, 34\% ikut serta karena merupakan anggota dari Masyarakat Peduli Api (MPA), 7\% tidak ikut serta karena tidak memiliki kemampuan, dan $2 \%$ tidak ikut serta karena beranggapan perusahaan sudah memiliki Regu Pemadam Kebakaran (RPK). PT
Finnantara Intiga berupaya melakukan perekrutan masyarakat menjadi karyawan, pemberian bibit karet (Hevea brasilliensis), dan pemberian bantuan kegiatan sosial seperti berobat gratis dan pembangunan sarana dan prasarana untuk kepentingan masyarakat (contoh: tempat ibadah).

\section{Saran}

Perlu ditingkatkannya strategi pengendalian kebakaran hutan yang lebih dititikberatkan pada pencegahan kebakaran hutan berupa penyuluhan yang lebih intensif tentang Penyiapan Lahan Tanpa Bakar (PLTB) atau cetak sawah serta perlu diadakan papan peringatan bahaya kebakaran hutan di beberapa lokasi yang rawan terbakar. Partisipasi masyarakat PT Finnantara Intiga dapat diwujudkan dengan lebih memperbanyak upaya peningkatan keahlian anggota MPA di daerah tersebut, seperti pelatihan dan pembinaan yang intensif, pengembangan dan penguatan masyarakat dalam pengendalian kebakaran hutan dan lahan.

\section{DAFTAR PUSTAKA}

[EEPSEA and WWF] Economy and Environment Progran for South East Asia and World Wildlife Fund. 1998. Interim results of Study on the Economic Value of Haze Damage in Southest Asia. Jakarta (ID) : EEPSEA and WWF.

[Finnantara Intiga]. 2015. Rencana Kerja Tahunan 2015. Sanggau (ID): PT Finnantara Intiga.

[Kemenhut] Kementerian Kehutanan. 2012. Disampaikan dalam makalah Dr. Haryadi Himawan tentang Perhutanan Sosial sebagai Pembangunan Kehutanan. Seminar Nasional dalam membangun tata kelola kehutanan yang baik. Jakarta (ID): 4 Desember 2012.

Brown AA, KP Davis. 1973. Forest Fire Control \& Use. Amerika Serikat (US): Mc Graw Hill Company.

Chandler C, Cheney P, Thomas P, Trabaud L, Williams D. 1983. Fire In Forestry Vol I: Forest Fire Behavior and Effects. Canada (CA): John Wiley and Sons

Peraturan Pemerintah Nomor 4 Tahun 2001 tentang Pengendalian Kerusakan dan atau Pencemaran Lingkungan Hidup Yang Berkaitan Dengan Kebakaran Hutan dan Lahan.

Peraturan Pemerintah Nomor 3 Tahun 2008 tentang Tata Hutan dan Penyusunan Rencana Pengelolaan Hutan, Serta Pemanfaatan Hutan, ditetapkan bahwa ketentuan usaha pemanfaatan hasil kayu pada hutan alam, restorasi ekosistem, hutan tanaman.

Saharjo BH, WC Adinugroho, INN Suryadiputra, L Siboro. 2005. Panduan Pengendalian Kebakaran Hutan Gambut. Bogor (ID): Wetlands International.

Sugiyono. 2005. Memahami Penelitian Kualitatif. Bandung (ID): CV. Alfabeta.

2008. Metode Penelitian Kuantitatif Kualitatif dan R\&D. Bandung (ID): CV. Alfabeta. 
Sumantri. 2003. Perencanaan Pencegahan Kebakaran Hutan. Pencegahan Kebakaran Hutan. hlm: 192 204. Bogor (ID): Fakultas Kehutanan IPB.

Suratmo FG. 1974. Perlindungan Hutan. Bogor (ID): IPB Press.

Suratmo FG. 1999. Pedoman Nasional Perlindungan Hutan Terhadap Kebakaran: Pengendalian Kebakaran Hutan Terpadu di Indonesia. Bogor (ID): IPB Press.

Suratmo FG, EA Husaeni, dan N Surati Jaya. 2003. Pengetahuan Dasar Pengendalian Kebakaran Hutan. Bogor (ID): Fakultas Kehutanan IPB.
Suyanto S. 2002. Makalah Kebakaran Hutan Latar Belakang Penyebab Terjadinya Kebakaran Hutan di Indonesia Serta Upaya Pemulihan Yang Bisa Dilakukan, Workshop Perhitungan Beban Biaya Pemulihan Kebakaran dan Pencemaran Lingkungan Hidup akibat Pembakaran Hutan dan Lahan. Bogor (ID): Fakultas Kehutanan IPB.

Syaufina L. 2008. Kebakaran Hutan di Indonesia. Malang (ID): Bayumedia.

Tacconi. 2003. Kebakaran Hutan di Indonesia: Penyebab, Biaya dan Implikasi Kebijakan. Bogor (ID): CIFOR. 